\title{
BANKING AND FINANCIAL TECHNOLOGY (FINTECH) ISLAMIC INTEGRATION WITH COLLABORATIVE MODELS
}

\author{
Swastiratu Cindy, Baga Lukman Mohammad, Saptono Imam Teguh \\ School of Business, IPB University, Indonesia \\ *E-mail: swastiratucindy@gmail.com
}

\begin{abstract}
This research aims to formulate appropriate collaboration models for Islamic banking and fintech integration. The research was carried out by descriptive analysis method. The tools used at this study consist of EFE (External Factors Evaluation) analysis, IFE (Internal Factors Evaluation) analysis, IE (Internal External) matrix analysis, SWOT matrix analysis, and ANP analysis. The results of the analysis show Islamic banking and fintech external strategic factors include 5 opportunities and 5 threats. The Islamic banking internal strategic factors include 6 strengths and 4 weaknesses. In this study Islamic banking and fintech obtained EFE 3.11 and IFE 3.00. The position of Islamic banking and fintech in the IE matrix is cell IV which means grow and build with a choice of intensive and integrative strategies. The results of the SWOT analysis provide show Islamic banking and fintech with several strategies that can be implemented, namely in the form of 2 SO strategies, 2 ST strategies, 3 WO strategies, and 1 WT strategy. The choice of strategy is then determined by the priorities of each strategy and alternative strategies that will be used for Islamic banking and fintech collaboration.
\end{abstract}

\section{KEY WORDS}

Banking, Fintech, information technology, collaboration.

As information technology develops and is supported by rapid internet penetration, a number of digital financial services have emerged that make it easier for people to make transactions and obtain financing. This digital financial service is called financial technology which is then abbreviated as fintech. Distribution of Fintech companies in Indonesia in 2018 can be seen in Figure 1 based on the Fintech News Singapore survey. Indonesians use more payment-based fintech services with a percentage of $38 \%$ and followed by loan services of $31 \%$.

This shows that the availability of fintech in Indonesia is able to help the government in providing wider and more efficient payment and loan services. The total value of investment in fintech in Indonesia in 2017 reached 2.29 trillion rupiah according to Daily Social and Statistics data on the Fintech Indonesia Report (2018). The World Economic Forum (2015) report in the Fintech Indonesia article predicts that Indonesia will become one of the largest digital markets in Southeast Asia by 2020. This prediction shows the opportunity for the development of digital financial services in Indonesia in the near future to meet financial service needs for society.

Application of financial technology to improve the efficiency of operational activities and the quality of bank services to its customers. This is due to utilization Financial technology is in line with the growing needs of the community will be online-based financial services and use of internet media for data access digital. This will increase the existence of more Islamic banking be competitive in financial markets and also help accelerate financing processes in Islamic banks with applications that are easy, efficient and effective with access wider. The financing process is faster and measurable by mitigating risks that can done early with the fintech system.

Based on this, it becomes an opportunity for Islamic banking to use of fintech. This opportunity is supported by Islamic bank products can meet all community needs. From the problem of share growth Islamic banking market, product financing products that have characteristics from the focus of Islamic banking on the existence of national and 
international markets. Various developments in fintech industry, regulator recognition, and potential a broad community of financial access, allows for a strategy that connects Islamic banking and fintech banking.

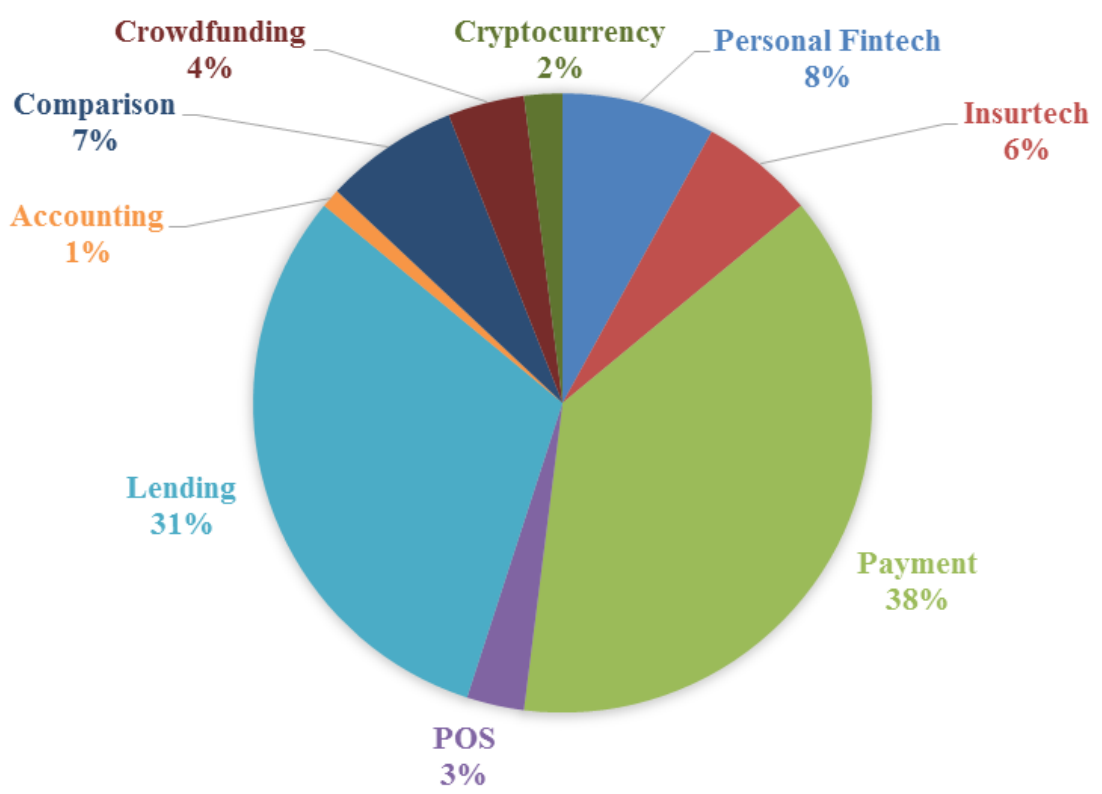

Figure 1 - Fintech Distribution in Indonesia in 2018

The collaboration model between Islamic banking and fintech is, among others, when there are Islamic banking customers who will apply for loan funds however has not met the requirements of Islamic banking, Islamic banking will offering fintech loan products that have easier requirements compared to Islamic banking, and for these services, Islamic banks will get compensation or profit sharing from fintech who works with him. Based on the background and formulation of the problem above, the purpose of this study is:

1. Identifying strategic issues between Islamic banking and fintech;

2. Analyzing the formulation of appropriate strategies for banking integration and fintech Islamic;

3. Forming the right collaboration model for banking integration and fintech Islamic.

\section{METHODS OF RESEARCH}

This research was conducted for two months from April to May 2019. Data collection locations, interviews, and filling out questionnaires were conducted on Islamic banking (BNI Syariah and BSM), partners (Kerjasama.com, Ammana.id), and regulators (OJK) in Jakarta. Observation and study of literature is the first step that needs to be done is to make an initial observation to get an overview of the actual conditions of the object to be studied. Quantitative analysis is also used in weighting using pairwise comparison in the ANP method. Strategy priorities are determined by the ANP method. Sources of data use primary data and secondary data. Data collection techniques through interviews and questionnaires are carried out by involving the CEO and manager of the relevant divisions / departments. Secondary data obtained through literature studies / literature studies relating to banking and Islamic fintech were processed by researchers. The sampling technique is done by purposive sampling technique or judgment sampling. The main criteria that make consideration are internal parties related to Islamic banking and fintech.

Survey respondents were determined by purposive sampling, which consisted of internal and external respondents. The internal part who is the respondent is a member of the Board of Directors Islamic banking. While the external part consists a member of the Board of Directors Islamic fintech. To get an initial picture of strategic factors, focus group discussions were conducted with the general managers. Then determine the strategic factors 
of the external and internal business environment. Examination of the company's external and internal environment is very important in the strategy planning process (Arslandere and Ocal 2018). The framework for analyzing the external environment is using PESTEL (Political, Economy, Social, Technology, Environment, Legal) (Sammut-Bonnici and Galea 2015).

After that the weighting and rating of the strategic factors is done by using a questionnaire. Weighting and rating of strategic factors produces EFE and IFE matrices which are then mapped into the Internal-External (IE) matrix. The External Factors Evaluation (EFE) and Internal Factors Evaluation (IFE) matrices are the initial input matrices that summarize the synopsis of major environmental opportunities and threats and the company's main strengths and weaknesses, and how they affect the company (Capps and Glissmayer 2012). The combined values of EFE and IFE are mapped into the InternalExternal matrix which is divided into 9 cells (David and David 2017). The use of this IE matrix is to obtain business strategies at the corporate level (Winardi 2014).

The SWOT matrix is used to develop selected grand strategies from the IE matrix into several business strategies (Budiman et al. 2018). After getting the weight value from each perspective, the questionnaire made to determine the priority of the strategy with the ANP method, assisted with supporting application, namely super decision 2.0 which is an application program of ANP theory (Saaty 2003). In the ANP method, the data used is data primary obtained from the results of interviews (in-depth interviews) with experts, practitioners, and regulators who have an understanding of the issues discussed. Followed by filling out questionnaires with respondents. Data is ready for processing in ANP are the variables of respondents' assessment of the problem being the object research on a numerical scale (Suhendi 2012).

The questions in the ANP questionnaire are pair comparisons (pairwise comparison) between elements in the cluster to find out which of the two greater influence (more dominant) and how much the difference is seen from one side. According to Saaty (1996) a numerical scale of 1-9 is used in giving opinion scores based on the level of accuracy indicated by the value Root Mean Square (RMS) and Median Absolute Deviation (MAD).

\section{RESULTS OF STUDY}

Banks are one of the financial institutions that have an important role as financial intermediaries in the economy of a country. Aside from being a place to store funds, the bank is also a place to borrow funds. At present the bank is an institution that cannot be separated from people's lives. Among other functions banks in the modern world are as providers of electronic shopping payments, telephone bills, electricity bills, and other payments.

Islamic banks are banks that are based on Islamic economic systems. Islamic banks were initially developed as a response from economic groups and Muslim banking practitioners who tried to accommodate the pressure of various parties who wanted financial transaction services to be carried out in line with moral values and Islamic sharia principles. According to Law Number 10 Year 1998 Article 1 Paragraph 13 concerning banking states that what is meant by sharia principles is an agreement based on Islamic law between banks and other parties for depositing funds and / or financing business activities, or other activities declared in accordance with sharia, between other financing is based on the principle of profit sharing, financing based on equity participation, the principle of buying and selling goods by obtaining profits, or financing capital goods based on the principle of pure rent without choice. Or with the transfer of ownership of goods rented from the bank by another party.

Islamic finance in Indonesia has grown more than two decades since the operation of Bank Muamalat Indonesia, as the first Islamic bank in Indonesia. The development of Islamic finance has resulted in various achievements, from increasingly increasing products and services, to increasing infrastructure that supports sharia finance. Even in the global market, Indonesia is among the top ten countries that have the largest Islamic financial index in the 
world. However, the growth of Islamic finance has not been able to keep up with conventional financial growth.

The emergence of financial technology (fintech) is one proof of the development of digital-based technology which is a new innovation and has an impact on all economic activities. Fintech is a business that focuses on providing financial services using modern software and technology. The development of conventional fintech was followed by the development of sharia-based fintech. There is a difference between Islamic fintech and conventional fintech. Because the suitability of the transactions carried out must be in accordance with sharia rules both in harmony and conditions in the contract. The emergence of sharia fintech is in line with changes in increasingly advanced technology so that human lifestyles also change according to the times.

Peer to peer lending (P2P) is an online borrowing and borrowing platform. Through an online platform transparency and information disclosure make access to capital easier and affordable. Borrowers with limited access get an easy process and an affordable rate. On the other hand, fund owners can obtain investment alternatives that are more profitable than conventional investment instruments. Alamisharia.co.id, Ammana.id, and Kapitalboost.com are sharia fintech services that use the principle of P2P.

Crowd funding is a fundraising process to start a business whose source of funds comes from a large number of people. Collection of funds with a certain time limit, for example 30 to 60 days, and the process is done through an online platform. Community funding is an initiative to raise money for a new project proposed by someone by collecting small to medium sized investments. Examples of sharia fintech in Indonesia engaged in crowdfunding include Collaboration.com and Ethiscrowd.com.

Electronic payments as all payments initiated, processed and received electronically. E-Payment requests have arisen because of the presence of online stores (Hartmann 2006). The first electronic payment solution, for example online banking, was strongly inspired by predefined account-based bank transfers. Since then there have been innovative and easy to use solutions and are more in line with the needs of traders and customers (Dahlberg et al. 2007). The electronic payment process includes the transfer of a certain amount of money from the payer to the recipient of payment through an independent electronic payment mechanism (Weir 2006).

External environment analysis aims to identify external strategic factors. This research uses PESTLE analysis (Politics, Economy, Social, Technology, Legal, Environment). Identification of external strategic factors is carried out by direct interviews with company respondents, as well as additional information obtained from the literature. Using the PESTLE analysis framework, there were 5 factors including opportunities and 5 factors which included threats to Islamic banking and fintech (Table 1). The EFE calculation of islamic fintech produces a value 3.110. This figure shows that Islamic fintech's external factors have good potential for business.

Table 1 - External Factors Evaluation (EFE) Matrix

\begin{tabular}{|c|c|c|c|c|}
\hline Factors & $\frac{\text { Weight }}{\text { (a) }}$ & $\frac{\text { Rating }}{\text { (b) }}$ & $\begin{array}{c}\text { Skor } \\
\left(c=a^{\star} b\right)\end{array}$ & Ranking \\
\hline \multicolumn{5}{|l|}{ OPPORTUNITIES } \\
\hline 1. Technological advancements facilitate product development & 0.118 & 4 & 0.472 & 1 \\
\hline 2. The Islamic market is still very wide open & 0.109 & 4 & 0.436 & 2 \\
\hline 3. Changes in the economic situation and pricing with conventional banks & 0.126 & 3 & 0.378 & 4 \\
\hline 4. Increased public awareness to practice according to sharia & 0.097 & 4 & 0.388 & 3 \\
\hline $\begin{array}{l}\text { 5. There is excess liquidity in banks in the Middle East } \\
\text { THREATS }\end{array}$ & 0.079 & 3 & 0.237 & 5 \\
\hline 1. A security and political situation that does not support foreign investment to develop & 0.116 & 2 & 0.232 & 3 \\
\hline 2. Geographical conditions determine product development & 0.092 & 1 & 0.092 & 5 \\
\hline 3. The framework and instruments of sharia regulations are incomplete & 0.103 & 4 & 0.412 & 1 \\
\hline 4. There are still differences of opinion among scholars regarding sharia principles & 0.085 & 2 & 0.170 & 4 \\
\hline 5. The difficulty of changing people's mindsets & 0.072 & 4 & 0.288 & 2 \\
\hline Total $(A+B)$ & 1 & & 3.110 & \\
\hline
\end{tabular}


The internal environment for Islamic banking is covering factors within the company that are relevant and influential for the company's business. By using the company's functional analysis framework in the form of marketing, operational, human and financial resources, six factors were included including strengths and 4 factors including weaknesses in Islamic banking (Table 2). The IFE calculation of islamic fintech produces a value 3.000. This figure shows that Islamic banking's internal factors have good potential to be optimized to choose a more aggressive business strategy to encourage growth.

Table 2 - Internal Factors Evaluation (IFE) Matrix

\begin{tabular}{|c|c|c|c|c|}
\hline \multirow{2}{*}{ Factors } & Weight & Rating & Skor & Ranking \\
\hline & (a) & (b) & $\left(c=a^{*} b\right)$ & \\
\hline \multicolumn{5}{|l|}{ STRENGTHS } \\
\hline 1. Human resources that uphold management policies & 0.119 & 4 & 0.476 & 3 \\
\hline 2. A sense of togetherness and mutual belonging between existing human resources & 0.113 & 4 & 0.452 & 4 \\
\hline 3. There is control over quality human resources & 0.119 & 4 & 0.476 & 2 \\
\hline 4. Strong capital structure for product development & 0.088 & 3 & 0.264 & 6 \\
\hline 5. A more equitable system of sharia & 0.107 & 4 & 0.428 & 5 \\
\hline $\begin{array}{l}\text { 6. There are other control institutions such as the sharia supervisory board } \\
\text { WEAKNESSES }\end{array}$ & 0.125 & 4 & 0.500 & 1 \\
\hline 1. Product codification and regulatory standards are still minimal & 0.080 & 1 & 0.080 & 4 \\
\hline 2. Sharia operational efficiency is still not optimal & 0.071 & 2 & 0.142 & 1 \\
\hline 3. Sharia HR does not fully understand the sharia business & 0.108 & 1 & 0.108 & 3 \\
\hline 4. Limitations on sharia marketing networks & 0.060 & 2 & 0.120 & 2 \\
\hline Total $(\mathrm{A}+\mathrm{B})$ & 1 & & 3.000 & \\
\hline
\end{tabular}

Merging EFE values and IFE banking values and sharia fintech are plotted in the IE matrix resulting in a value $(3.110,3.000)$ in quadrant IV (Figure 2). Quadrant position I illustrates that the company is currently in growth and build stage with an appropriate grand strategy that is intensive (market penetration, market development, product development) or integrative (forward integration, backward integration, horizontal integration). This position affects the choice of strategies arranged in the next stage.

TOTAL SKOR IFE

$\begin{array}{lll}\text { Strong } & \text { Medium } & \text { Weak } \\ 4.0-3.0 & 2.99-2.0 & 1.99-1.0\end{array}$

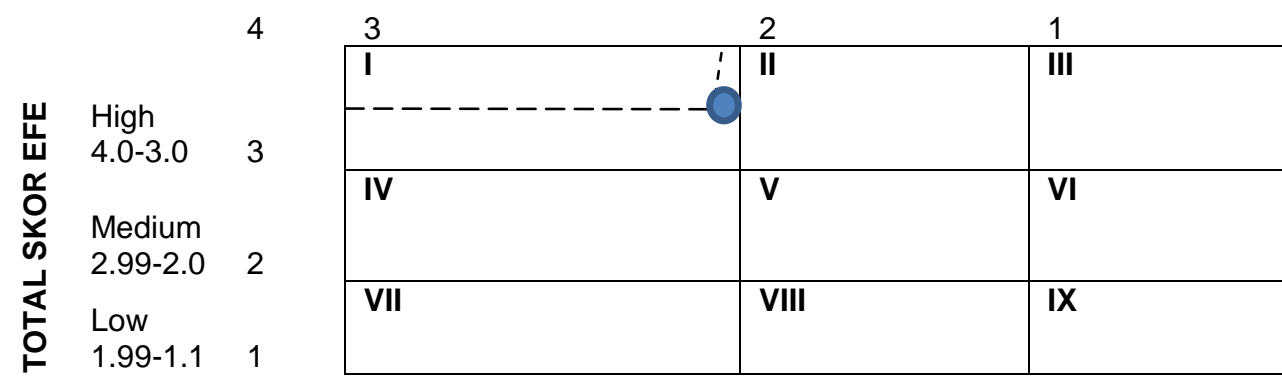

Figure 2 - Company position on the Internal-External matrix

After obtaining the grand strategy from the IE matrix, then the strategy analysis was carried out using the SWOT matrix. Strategy selection is mainly focused on S-O (StrengthsOpportunities) strategy, which is a strategy that prioritizes the use of strength owned by the company to optimally utilize business opportunities for companies. Even so, Islamic banking and fintech continue to consider several W-O, S-T, and W-T strategies that are really needed for companies to be able to increase business growth.

After determining the rating with EFE and IFE matrices from each SWOT perspective, the target strategy and the next step are weighting feedback and determining the priority of strategies from each element of the IE matrix results and alternative strategies that will be used for sharia banking and fintech collaboration using ANP. In determining alternative 
strategic priorities used by combining the opinions of five respondents or expert experts consisting of internal companies, namely two CEOs of sharia fintech, two general managers of sharia banking, and one respondent or other experts, namely regulators from external companies that have the capacity and deep understanding of Islamic banking and fintech.

Table 3 - SWOT Matrix for Islamic banking and fintech business development

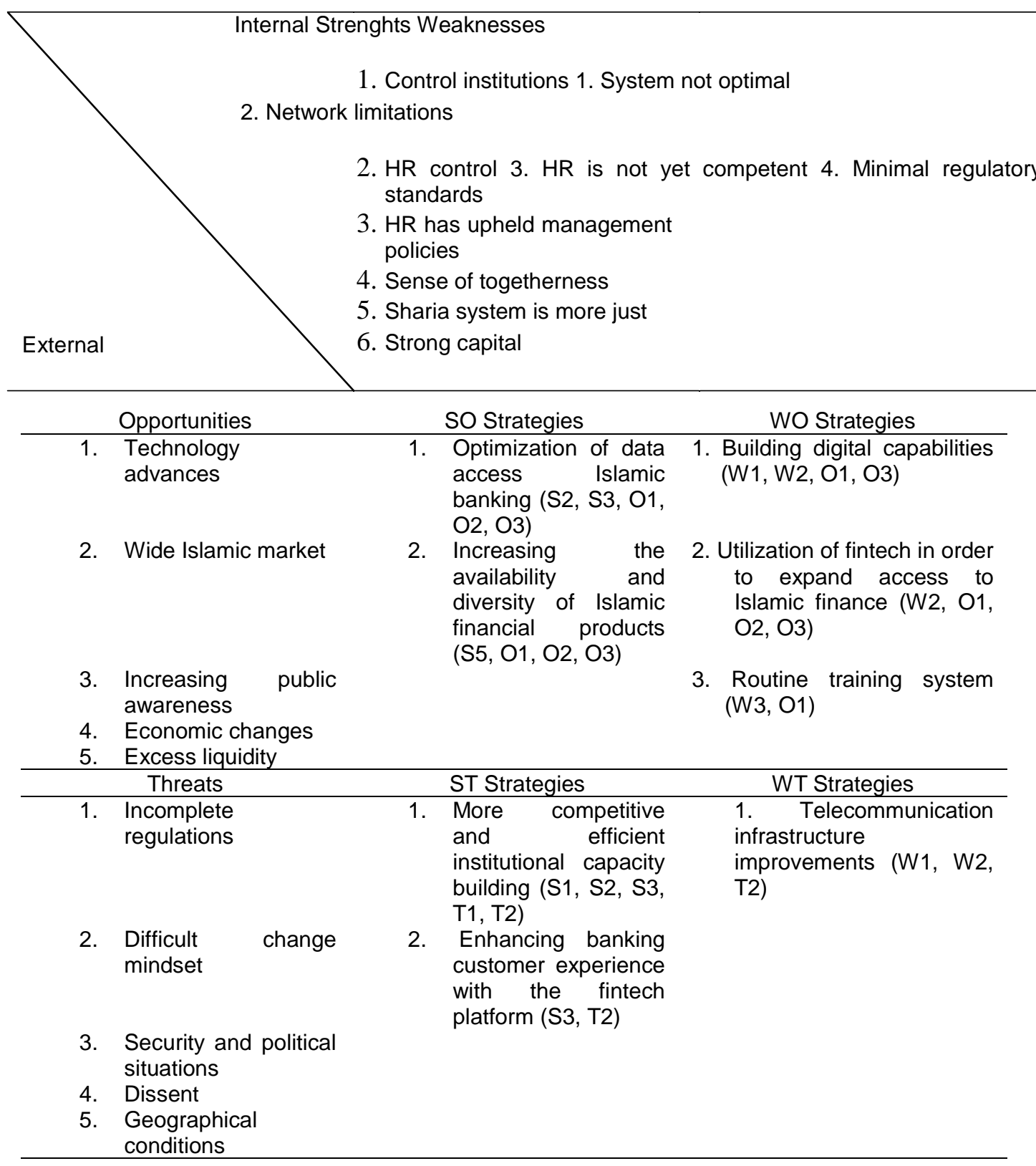

In ANP there are two parts, namely part of the network consisting of criteria and subcriteria and the second part is the influence between elements and clusters. This network has three clusters, namely the SWOT perspective, strategic objectives, and alternative strategies. In each cluster there are several elements in it, in the SWOT perspective there are four elements, four elemental strategy objectives, and four alternative strategies. The general ANP framework can be seen in Figure 3.

Based on the ANP results, determining the priority of strategies in banking collaboration and sharia fintech which is processed with super decision software can be seen in Table 12 where the greater the weight produced the higher the priority level of the strategy. In the perspective cluster, the main priority in the context of banking collaboration 
and sharia fintech is the power perspective with a weight of 0.3654 . The second priority is the opportunity perspective with a weight of 0.3171 . The threat perspective is the third most important priority in the perspective cluster with a weight of 0.2018 . The last priority in the perspective cluster is weakness with a weight of 0.1156 .

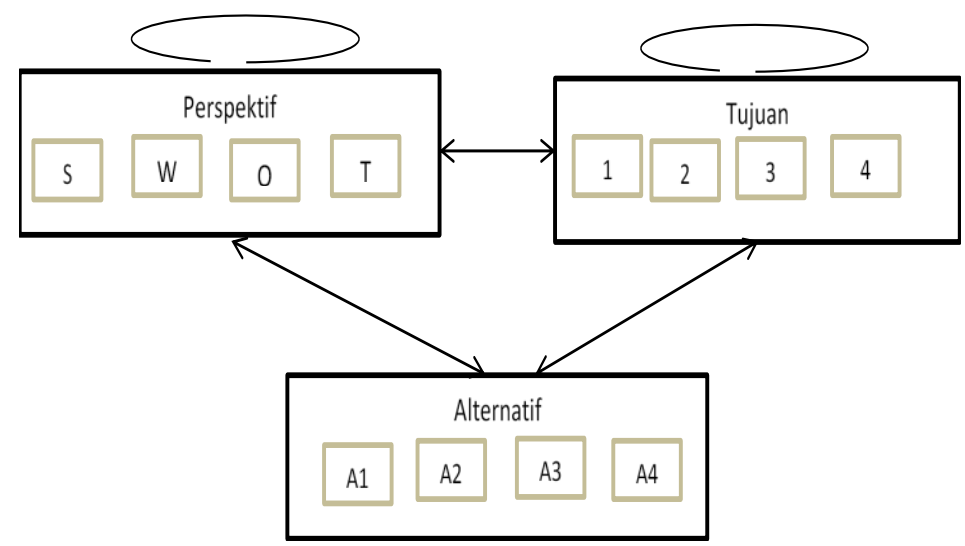

Figure 3 - Sharia banking and fintech collaboration strategy framework with ANP

In the cluster strategy the target element which is the top priority is the design of sharia regulations by the regulator of 0.3983 . The second priority element is increasing the sharia marketing network with a weight of 0.2081 . Improving the quality of competent human resources is an element of the strategic target cluster that the company wants to achieve with a weight of 0.2054 . The last priority is to increase the volume of product sales in either banking or Islamic fintech with a weight of 0.1880 .

ANP results on alternative strategies show that Islamic banking and fintech must synergize to accelerate sharia business growth with a weight of 0.4178 . The utilization of the Islamic fintech system carried out by Islamic banking to reach customers is the second priority in the alternative strategy cluster with a weight of 0.2859 . The third priority that becomes an alternative to banking collaboration and sharia fintech strategy is that Islamic banks build digital capabilities with the Islamic fintech platform with a weight of 0.1700 . The routine training system is the last priority in alternative strategies with a weight of 0.1251 .

\section{MANAGERIAL IMPLICATIONS}

The managerial implications of this research are manifested in a banking collaboration model and sharia fintech as a result of the SWOT matrix. The collaboration model is prioritized through ANP analysis in Figure 8. To obtain the right collaboration model for Islamic banking and fintech. The collaboration model was built based on 4 alternative strategies resulting from the SWOT matrix. The order of priority strategies to be carried out by the company is determined based on the highest weighting value.

Islamic banking and fintech will develop optimally with a collaboration model. Fintech sharia by providing easier and faster financial access. The first collaboration model is CoLending, which is the distribution of funds to help capitalize a business that cannot yet be served by Islamic banking. For example, access to small business funding can be transferred to Ammana.id. Ammana.id is a community-based loan distributor.

Co-Marketing collaboration model, which is product marketing. Islamic banks can market products through the fintech platform. For example, when a customer has not met Islamic banking requirements, Islamic banking will offer sharia fintech products. This is because Islamic fintech has requirements that are easier than Islamic banking. And vice versa, when sharia fintech customers meet banking requirements, fintech sharia will offer sharia banking products. 
The Co-Sharing collaboration model is sharing profits and losses. For example Kendang. A fintech platform engaged in Islamic investment that connects investors with farmers in the area. Kendang.in uses a profit sharing system.

Co-Caring and Co-Charity collaboration model that is caring. Islamic banking can use fintech sharia in the implementation of corporate social responsibility with the aim of providing added value to all stakeholders including internal companies to support the company's growth. The implementation of Islamic banking collaborates with online shariabased fintech based donations and fundraising.

\section{CONCLUSION}

In this study the conclusion is the formulation of the answers to the objectives of the study. The conclusions of this study are as follows:

1. Banking and Islamic fintech have the potential to be able to take advantage of opportunities in the financial industry. With internal banking capital and fintech capital as adequate financial services in terms of strength, namely the existence of other control institutions such as DPS, the control of human resources, human resources that uphold management policies, a fairer system, and a strong capital structure for product development. So the opportunity for technological advances in the industrial era 4.0 can be optimized with the right strategies to support the expected business growth.

2. Analysis of IE positions banking and Islamic fintech in quadrant I with a grand strategy grow and build with a choice of intensive and integrative strategies. The focus of the strategy in accordance with these positions is on the S-O (aggressive) strategy with 2 strategies, the W-O (conservative) strategy with 3 strategies, the S-T (competitive) strategy with 2 strategies, and the W-T strategy (defensive) with 1 strategy.

3. With the internal strength of Islamic banking and fintech, all of these strategies can be implemented by management. The banking collaboration model and sharia fintech were analyzed using ANP. Islamic banks and finteches synergize to improve the Islamic finance business.

\section{RECOMMENDATIONS}

Determination of sharia banking and fintech collaboration models is made at the corporate level so that to implement it a strategy must be made at the functional level as the development of work programs that have been prepared.

This strategy analysis is based on current conditions by considering the foresight industry for the company's business in the future, so it is advisable for management to periodically evaluate the suitability of the strategy with the situation of the business environment both internally and externally.

To enrich banking related literature and fintech sharia, further research is recommended from various aspects such as external parties (banking users and Islamic fintech) and regulators.

\section{REFERENCES}

1. Abdi A, Ashouri M, Jamalpour G, Sandoosi SM. 2013. Overview SWOT analysis and its application in organizations. Singaporean Journal of Business and Management [internet]. [diunduh pada 2019 Maret 24]; 1(12):69-74. Tersedia pada: https://pdfs.semanticscholar.org/83ba/2d69b3fe31fe9fad64b4dd f87a4dd10eca1f.pdf.

2. Algifari. 2010. Analisis Regresi, Teori, Kasus, and Solusi Edisi Kedua. Yogyakarta (ID): BPFE UGM.

3. Arslandere M, Ocal Y. 2018. SWOT analysis as a tool for strategic management and an implementation in a firm in machine industry. Conference paper.

4. Budi W. 2017. Analisa regulasi fintech dalam membangun perekonomian di Indonesia . Jurnal Ekonomi and Manajemen Bisnis. 4(2). 
5. Budiman I, Tarigan UPP, Mardhatillah A, Sembiring AC, Teddy W. 2018. Developing business strategies using SWOT analysis in a color crackers industry. J. Phys.: Conf. Ser.

6. Burhan. 1984. Management Control System. Jakarta (ID): Erlangga.

7. Diardo L. 2018. Analisis transaksi pembayaran menggunakan fintech pada UMKM di Indonesia: pendekatan adaptive structuration theory [Tesis]. Jakarta (ID): Universitas Islam Indonesia.

8. Duncan WJ. 1995. Strategic Management of Health Care Organization Second Edition. Oxford (UK): Blackwell Business.

9. David FR, David FR. 2017. Manajemen Strategik: Suatu Pendekatan Keunggulan Bersaing-Konsep. Puspasari N, Puspitasari LN, penerjemah. Jakarta (ID): Penerbit Salemba Empat. Terjemahan dari: Strategic Management: A Competitive Advantage Approach, Concepts and Cases, 15th ed.

10. De Kluyver CA, Pearce II JA. 2009. Strategy: A view from the Top (An Executive Perspective). New Jersey (US): Pearson Education.

11. Djordjević B. 2014. Strategy analysis and choice. MEST Journal. 2(2):42- 50.doi: 10.12709/mest.02.02.02.05.

12. Gurel E, Tat M. 2017. SWOT Analysis: A theoretical review. The Journal of International Social Research. 10(51):994-1006.

13. Hasibuan HM. 2007. Dasar-dasar Perbankan. Jakarta (ID): Bumi Aksara.

14. Hidayah MT. 2018. Kolaborasi bank wakaf and teknologi finansial (fintech) untuk pengelolaan wakaf di Indonesia. Jurnal Ekonomi and Bisnis. 3(1).

15. Hunger JD and Wheelen TL. 2003. Manajemen Strategis. Yogyakarta (ID): Andi Offset.

16. Ikatan Akuntansi Indonesia. 2002. Standar Akuntansi Keuangan PSAK Nomor 31 Perbankan. Jakarta (ID): Salemba Empat.

17. Imanuel AWC. 2017. Analisis SWOT implementasi teknologi finansial terhadap kualitas layanan perbankan di Indonesia. Jurnal Ekonomi and Bisnis. 20(1).

18. Irma M, Inayah AR, Bella GN. 2018. Peran fintech dalam meningkatkan keuangan inklusif pada UMKM di Indonesia (pendekatan keuangan syariah). Jurnal Ekonomi and Perbankan Syariah. 3(1).

19. Jack CP. 2000. Kamus Analisa Politik. Jakarta (ID): Rajawali.

20. Muhammad and Muhamad. 2013. Efisiensi bank umum syariah menggunakan pendekatan two stage data envelopment analysis. Buletin Ekonomi Moneter and Perbankan.

21. Mulyadi. 2001. Balanced Scorecard: Alat Manajemen Kontemporer untuk Pelipatgandaan Kinerja Keuangan Perusahaan. Jakarta (ID): Salemba Empat.

22. Natasha $P$, Devie. 2013. Analisa pengaruh strategic planning terhadap keunggulan bersaing and kinerja perusahaan. Business Accounting Review. 1(2):185-196

23. Nugraha. 2010. Manajemen Strategis dalam Pengelolaan Bisnis. Jakarta (ID): Andi Offset.

24. Ommani AR. 2011. Strength, weaknesses, opportunities and threats (SWOT) analysis for farming system business management: Case of whear farmers of Shadervan Distric, Shoushtar Township, Iran. African Journal of Busines Management. 5(22):9448-9454. Tersedia pada: http://www.academicjournals.org/AJBM.

25. Parnell JA. 2010. Strategic clarity, business strategy and performance. Journal of Strategy and Management. 3(4):304-324.

26. Pearce JA, Robinson RB. 2009. Formulation, Implementation and Control of Competitive Strategy. New York(US): McGraw-Hill.

27. Pudjadi T, Kristianto, Tommy A. 2007. Analisis untuk perencanaan strategi sistem teknologi informasi pada PT Ritrans Cargo. Seminar Nasional Aplikasi Teknologi. 1(1): 712.

28. Rangkuti F. 2004. Analisis SWOT Teknik Membedah Kasus Bisnis. Jakarta (ID): Gramedia Pustaka Utama. 
29. Ridwan M. 2018. Analisis SWOT financial technology (fintech) pembiayaan perbankan syariah di Indonesia (studi kasus 4 bank syariah di kota Medan). Jurnal Ekonomi and Perbankan Syariah. 3(2).

30. Sammut-Bonnici T, Galea D. 2015. SWOT Analysis. Wiley Encyclopedia of Management. Edited by Professor Sir Cary L Cooper. New York (USA): John Wiley and Sons.

31. Schoeder R. 2010. Operations Management. 5tn Ed. New York (USA): Barron's Educational Series Inc.

32. Taswan. 2006. Manajemen Perbankan: Konsep, Teknik, and Aplikasi. Yogyakarta (ID): UPP STIM YKPN.

33. Umar H. 2003. Strategic Management in Action. Jakarta (ID): Gramedia Pustaka Utama.

34. Verra NT. 2013. Pengaruh pendidikan and pelatihan terhadap peningkatan kinerja karyawan pada Balai Pelatihan Teknis Pertanian Kalasey. Jurnal Riset Ekonomi, Manajemen, Bisnis, and Akuntansi. 1(3).

35. Muhammad SH. 2017. Linkage pembiayaan and manajemen risiko berbasis modal sosial pada financial technology: strategi peningkatan pembiayaan inklusif. Jurnal Ekonomi and Manajemen. 3(2).

36. Mulyadi. 2001. Balanced Scorecard: Alat Manajemen Kontemporer untuk Pelipatgandaan Kinerja Keuangan Perusahaan. Jakarta (ID): Salemba Empat.

37. Ridwan M. 2018. Analisis SWOT financial technology (fintech) pembiayaan perbankan syariah di Indonesia (studi kasus 4 bank syariah di kota Medan). Jurnal Ekonomi and Perbankan Syariah. 3(2).

38. Saaty TL. 2003. Decision-making with the AHP: Why is The Principal Eigenvector Necessary. European Journal of Operational Research. 145: 85-91.

39. Supriyadi and Masjono. 2015. Prinsip ekonomi dalam perbankan syariah. Jurnal Ekonomi and Bisnis. 1(1).

40. Svetlana S and Iriana KM. 2011. Fintech as financial innovation-the possibilities and problems of implementation. Journal European Research Studies. 20(3A). 